\title{
Compliance to Nigeria Broadcasting Code on Religious Programs: A Comparative Study of Borno Radio Television (BRTV) and Nigerian Television Authority (NTA) Maiduguri
}

\author{
Ibrahim Uba Yusuf* \\ Department of Mass Communication, University of Maiduguri, PMB 1069 Maiduguri, Borno State, Nigeria \\ Musa Usman \\ Department of Mass Communication, University of Maiduguri, PMB 1069 Maiduguri, Borno State, Nigeria \\ Adamkolo Mohammed Ibrahim \\ Department of Mass Communication, University of Maiduguri, PMB 1069 Maiduguri, Borno State, Nigeria
}

\begin{abstract}
Since 1992, when the broadcast industry was deregulated coupled with the issuing of broadcast licenses to individuals and groups, the Nigerian broadcast industry has seen a mushrooming growth of religious programs on radio and television. Borno Radio Television (BRTV) and the Nigerian Television Authority (NTA) are two broadcast stations situated in Maiduguri, the capital of the Nigerian state of Borno where religion forms core part of the people's culture. Islamic religious preaching forms a key part of the stations' programs especially during the annual Ramadan fasting season. The broadcasting industry regulatory body in Nigeria, the National Broadcasting Commission (NBC) stipulates that religious programs should not exceed a $10 \%$ of the total programs of a particular broadcast outlet. Observations have revealed that a large percentage of BRTV and NTA's airtime is allocated to Islamic preaching during the 29- or 30-day Ramadan fasting period. However, is the airtime allocated to Islamic programs in those stations within the NBC $10 \%$ limits or not? To answer this research question, a comparative analysis was made of religious programs broadcast on the two broadcast outlets in the second quarter of 2019. The data were obtained using Key Informant Interviews with 5 personnel from BRTV, NTA and NBC in Maiduguri, and relevant official documents including the stations' program schedules were reviewed. Key findings suggest that the airtime allocated to religious programs were more than the $10 \%$ limit while BRTV Maiduguri allocated more airtime to religious programs than NTA Maiduguri. Also, Islamic religious programs were allocated more airtime than programs of other religions.
\end{abstract}

Keywords: Broadcasting, BRTV, Nigerian Broadcast Industry, NTA, Television, Religious Programs, NBC, Nigerian Broadcasting Code

DOI: $10.7176 / \mathrm{JPCR} / 47-01$

Publication date: December $31^{\text {st }} 2019$

\section{Introduction}

Since when Nigeria was granted political independence in 1960, the guarantee for the freedoms of "religious association, expression and practice" have been provided for in all the Constitutions drafted and promulgated (Adum, Ojiakor \& Nnatu, 2019). However, optimistic as this may be, there is one important thing that the Constitutions "have not granted citizens, in a straightforward, uncomplicated manner", and that is the "freedom to own and operate a broadcast medium" (Ukah, 2011, p.39). Nigeria is a multireligious and multicultural society; in a society such as this, "the role of the state with respect to religious communication is critical" as Hackett argues,

the role of public religion in a nation-state in political transition [as Nigeria obviously is] ...

provides an important insight into the mechanics of religious representation in the mediated public sphere. (2006, p.167)

Despite being an important factor of national identity and cohesion, religion has also been a critical factor of disunity and intolerance among Nigerians. As a matter of fact, there exists thorny and protracted history of "mutual suspicion" among the various Nigeria's religious and ethnic groups, a factor that is constantly regarded as one of the main reasons that the Nigerian Government has always treaded "a cautious approach to the liberalization of the media as well as the role of the state in the strategies of public representation of religion" (Johannes, 2008; Falola \& Heaton, 2008, p.238f).

The volatile nature of the Nigerian religious ambience has been indicated as having necessitated "the institutionalization of a policy of prior restraint on evangelizing communities in relation to religious broadcasting" (Bala, 2000, p.107; Ukah, 2011, p.40). Also, the abuse of religion and the use of the Mass Media to stir conflicts have led government to adopt new policies (see Appendix) with regard to religious broadcasting (Bala 2000). 
These are serious factors that cannot be ignored when discussing religious broadcasting in Nigeria. Hence, this paper notes that despite the role played by these factors in influencing the state policy on religious broadcasting, the Government's roles as a monopolizer in the pre-deregulation era and currently, "as a principal player in the media market" are responsible for the ambiguities manifested "in the state policies and politics of deregulation" of the broadcast media industry especially in light of religious broadcasting (see Ukah, 2011, p.40).

The utilization of conventional broadcast media by religious scholars especially during the Muslim Ramadan fasting period has made them emerged as stakeholders at the forefront of patronizing the media. The media have enormous derivable benefits - making huge turnovers to sustain operation. The priority intention of every scholar utilizing the broadcast media as a channel of communication is to garner more followership to his sect or create an identity or authority towards understanding what religion entails and how it should be practiced.

Taking into cognizance that clients with airtime purchasing power have access to the media, which serve as the only yardstick that guarantees which scholar features on, for example, a television or a radio show and when, poses a serious threat to the quality of the broadcast content. Although there is the doctrine of 'fairness', which seeks to provide the 'right of reply' to other party, say, aggrieved groups or individuals to counter-narrate allegations or criticisms, not all broadcast media seem to be comfortable with this journalism principle and code of ethics. As a matter of fact, available records have shown that many television and radio stations have violated one NBC code or another, particularly codes regarding broadcasting religion and have, consequently, been served with warning letters and even sanctioned.

Considering the powers of broadcast media "to form and influence thought, conduct and actions, it is appropriate and legitimate to prohibit licensed broadcast stations from fomenting and disseminating hate speech and national disunity" (Adum et al., 2019; Ibrahim, Pate \& Usman, in press; Ukah, 2011; p.44). However, as powerful as NBC is, considering the powers conferred to it by law, how has it been able to achieve compliance of the broadcast code in the Nigerian broadcast industry? This study was guided by several research questions which, if answered, could provide further understanding on NBC's and religious broadcasting in Nigeria. The questions are as follows: Has NBC been able to regulate television broadcasting considering religious programs and licensing? Are television stations adhering to the NBC code on religious broadcasting? How frequently do BRTV and NTA Maiduguri broadcast religious programs? What are the similarities in the mode of broadcast of religious programs between BRTV and NTA Maiduguri? Have there been any ethical violations in the broadcast of religious programs by BRTV and NTA Maiduguri?

\section{Literature Review}

\subsection{The Concept of Regulation}

e Characteristically, the broadcast media are powerful especially in the manner they shape public opinion, reaching millions of audiences in voice and image (Dominick, 2009; Okunna, 2005). The evolution and development of Nigerian broadcast industry is historical; and for 60 years, from 1932 to 1992, the state had monopolized the industry, using the broadcast media as tools for political, economic, social and cultural manipulation of the masses. The literature has consistently demonstrated that as much as the broadcast media possesses the potential to stimulate socio-economic development as witnessed in social agricultural developments in the South-East Asia (Anifowose, 2013; Ibrahim, 2017), the broadcast media also have the potential to be used as 'electronic weapons' to incite violence and cause war as seen in the chronic ethnoreligious conflicts in various parts of Nigeria (Adebiyi \& Salaudeen, 2016; Adum et al., 2019). Because of these and many other reasons, various governments deemed it necessary to keep its monopoly of controlling the broadcast industry. To understand what regulation is, Harvey defines the concept regulation which:

Involves intervention by the state in areas of economic, social or cultural life according to whatever political norms are characteristic of that nation state. Regulations may be issued by presidential decree, by religious prescription or by legislative action within a system of representative democracy. $(1999$, p.2)

Regulations can be governed directly by government, as it was in Nigeria before 1992 or through statutory outfits invested with some degree of autonomous powers by government such as National Broadcasting Commission (NBC) and the National Communications Commission (NCC). In the realm of broadcasting, regulation involves the authoritative issuance of permission or the granting of license to broadcasting organizations. The cultural norms of the society influence broadcasting regulation which, in turn, "contributes to the shaping of these norms and can at times have a significant impact on the form and content of programmes" (Harvey; 1999, p.3; Ihechu \& Okugo, 2013), thus, affecting the economic and management structures or political economy of broadcasting.

\subsection{Broadcast Regulations in Nigeria: The Need to Maintain Standards}

The constitutional provisions for the regulation and deregulation of the electronic media were boosted further by the promulgation of the National Broadcasting Commission (NBC) Decree +No. 38 of 1992, which was 
described as a major policy shift of the government. The Decree was signed into law on 20 August 1992 by the President Ibrahim Badamasi Babangida Military Administration and amended by Decree No. 55 of 1999, which was promulgated by then military Head of State, General Abdulsalami Abubakar on 26 May 1999, just three days before he vacated office (Ukah, 2011).

Decree No. 38 that established NBC, outlined its responsibilities the key of which include the following: (i) receiving, processing and considering applications for the ownership of broadcast stations (radio, television, cable, direct satellite, etc.); (ii) regulating and controlling the broadcast industry; (iii) maintaining the principle of equity and fairness in the broadcasting industry; (iv) receiving, considering and investigating complaints from members of the public (private and corporate) regarding broadcast contents and the conduct of broadcasting stations; (v) setting standards about the contents and materials for broadcast; and (vi) establishing a national broadcasting code. Furthermore, the NBC is to intervene and arbitrate in conflicts in the broadcast industry, ensure qualitative manpower development, monitor broadcasting for harmful emission, interference and illegal broadcast and set and apply sanctions, including revocation of licenses of defaulting stations (Malaolu, 2012; Tijani-Adenle, 2019). As spelled out in the law establishing the electronic media regulatory agency, NBC shall ensure that a licensed station shall be used to promote national interest, unity and cohesion and that it shall not be used to offend the religious sensibilities or promote ethnicity, sectionalism, hatred and disaffection among the peoples of Nigeria (NBC Decree 38, Section 9(1e)) .... The law setting up the NBC, and its amendment, deployed the concepts of "national interest", "public interest" and "interest of the public" six times (NBC Decree No. 38 Section 2(n); 4.4; 9(1e); 25(8d); NBC (Amendment Decree No. 55 Section 10(2B); 10(8A). Nowhere in the text were these concepts defined or given content as legitimate objectives to be safeguarded, protected, or promoted by private broadcasters. Particularly in Nigeria, what amounts to "national interest" often represents the interest of the politician(s) or a certain segment of the political class or elite who evoke the notion rather than the "common good", the good of the largest segment of the citizenry. Ordinarily, national interest may be conceptualised as any action, circumstances, policies, or decisions that are generally considered to benefit the nationstate as a whole. However, in Nigeria, as historical experience amply shows, the "state" is not often synonymous with the public or the citizens of the nation such that the interest of the abstraction called the "state" becomes co-terminus with what benefits the general public. (Ukah, 2011, p.44)

The so-called national/public interest stipulated in the NBC law also re-appeared in Section 10a, which prohibits the NBC from granting broadcast license to a religious organization. However, as mythical as the concept of 'national/public interest' may seem in this law, the law keeps mute over the reasons or justifications for the blanket ban (Adum et al., 2019; Ukah, 2011). This paper argues that this ban is uncalled for in as much as there is an explicit constitutional provision guaranteeing freedom of expression as well as the provision in the NBC law that explicitly requires applicants for broadcast license to "give an undertaking that the licensed station shall not be used to offend the religious sensibilities or promote ethnicity, sectionalism, hatred and disaffection among the peoples of Nigeria" (Ukah, 2011, p.44). Cited in Ukah (2001), Bala (2000, p.107) suggests that,

The decision not to license these [religious] stations may be due to the volatile religious atmosphere in the country, the abuse of religious speech in the past, the excessive politicization of religion, and the constant use of the mass media to heighten tensions. (p.45)

Some of the important aims of the deregulation of the broadcast industry is democratization of access and participation (Ibrahim et al., 2019) as well as plurality and diversity. However, this paper agrees with Ukah's (2011) argument that "the prohibition of ownership of broadcast media by religious organizations starkly sabotages this objective" (p.45).

\subsection{Major Approaches of NBC Broadcast Regulations in Nigeria \\ 2.3.1 Regulation through Licensing}

A primary function of NBC has to do with the licensing of broadcast organizations. NBC is required by law to make the requirements and procedure for acquisition of license public. For instance, NBC (2009) states that, "A prospective applicant must have a limited liability company registered with the Corporate Affairs Commission in which Nigerians hold majority shares. It's Memorandum of Association and Article of Association must include broadcasting" (p.1). Because NBC is not independent, its recommendations can be set aside, by the Minister and, or, the President. Section 9 (3) of Decree No. 38 created uncertainty in the process of securing a license when it states that, "Compliance with the requirements specified in subsection (1) of this section shall not entitle an applicant for the grant of licence" (Nwanze, 2003, p.250). The provision gives latitude for the licensing laws to be manipulated and for the licensing to be motivated by political considerations (Ihechu \& Okugo, 2013; Ukah, 2011).

Furthermore, an area of big concern is the license fees. The fees are expensive that they seemed to be fixed 
to make it extremely difficult for private broadcasters to obtain the license, which could affect public access and participation negatively (Ibrahim et al., 2019). Also, a license duration of only five-year cannot be said to be long enough for the organizations to recoup their investment (Ukah, 2011). This situation can force private broadcast media outfits to over depend on commercialization which, as Okunna (2005, p.89) citing Popoola (2004) describes the broadcast media as "shying away from their primary responsibilities of educating, informing and enlightening the citizenry... and violates the fundamental rights of people...to receive the right type of information".

\subsubsection{Regulation through Monitoring}

The NBC code stipulates that, "Every license is required to adhere to a minimum of $60 \%$ local broadcast content for open television and $80 \%$ local broadcast content for radio. The cable/satellite retransmission stations are mandated to reflect a minimum of $20 \%$ " (NBC, 2009, p.3). The code further requires that programs and advertisement for family belt shall be devoid of sex or overt sexual behavior, nudity, violence, bloodletting, smoking, alcohol, drug abuse, denigration of womanhood, offensive, lewd or vulgar language, expression and presentation, etc. and that family broadcast to be between the hours of $7 \mathrm{pm}$ and $10 \mathrm{pm}$ daily (a period when the family as a unit is presumed to be together to watch television). The code also prohibits provision of license for religion broadcasting (Ihechu \& Okugo, 2013; Ukah, 2011). These aspects are being monitored on daily basis by staff of the monitoring department of the NBC, spread across all state and zonal offices.

\subsubsection{Regulation through Sanctioning}

NBC uses four major types of sanctions to punish erring licensed broadcasters who violated either Decree 38 or the National Broadcasting Code. These include (i) license revocation, (ii) the shutting down or sealing up of a station or transmitter and (iii) the seizure or forfeiture of equipment and suspension of license (Ihechu \& Okugo, 2013, p.16; Ukah, 2011). Another type of sanctioning erring licensed broadcast station involves written warning, which is aimed at making the affected station to stop further violation of the code and deterring future breach of the code. Sanctioning is imposed with a given timeframe the expiration without compliance of which attracts a fine to be imposed. The last type of sanctioning involves fines and stiffer sanctions for not complying with earlier sanctions. However, the offences which can attract these types of sanctions can are not clear. However, the code is silent on what and what actually constitute a "serious breach". This scenario suggests the notion that NBC may be biased toward certain interests, which dictate "whether a station should be sanctioned or not", a circumstance that arises when NBC acts arbitrarily or goes against its own rules (Ihechu \& Okugo, 2013, p.17).

\subsection{Theoretical Framework}

The study is anchored on the Gatekeeping Theory. The Media Gatekeeping Theory focuses on media regulation of information flow. The term gate keeping was coined by an Austrian psychologist Kurt Lewin in 1947.

In the study of mass communication, the term refers to the process of filtering or blocking unwanted information or messages. The gate keepers refer to persons who (a) controls access to information; (b) influence decision making and actions; c) having influence. Lewin illustrated the role of the gate keeper with the role of a mother who determines what is good for her children. In this case, the gatekeeper is the owner of the publishing firm who has influence on decision making and action as well as having influence to manipulate information in the firm in order to conform to his/her interest. The gate keeper (owners) has to decide what to publish and what not to publish in a publication. Today, Mass Media play a gate keeping role as they decide what the people should watch, listen and enjoy. The gate keeping processes are dictated by the owners of the firm. The theory posits that gate keeping determines not only which information is selected, but also what the content and nature of messages, such as news, will be. The theory describes the powerful process through which events are covered by the mass media, explaining how and why certain information either passes through gates or is closed off from media attention. The rationale for using this theory is hinged on the selection process. Religious programmes are broadcast based on the proprietor's discretion, perhaps the audience and the ability of the sponsors to buy airtime in the broadcast station.

\section{Methodology}

\subsection{Research Design}

Qualitative survey approach was adopted, specifically, the key informant interview approach (Creswell \& Poth, 2017) and archival review or analysis (McBurney \& White, 2010). As Fontana and Prokos (2007) noted, "Interviewing is one of the most common and powerful ways in which we try to understand our fellow humans" (p.9). The interview approach was chosen because of two key reasons: (i) social science researchers often prefer interview methods to "understand the experiences of their subjects" (ii) interview provided the researcher the opportunity to understand, first-hand and in their own words, the participants' experiences (Tijani-Adenle, 2019, pp.76-77).

Archival review or analysis involves "answering empirical questions" (Goodwin, 2009, p.372) by using "factual information in existing records" (McBurney \& White, 2010, p.228) that have "already been gathered for 
some reason aside from the research project at hand" (Goodwin, 2009, p.386).

\subsection{Participants and Sampling}

Using a purposive sampling technique, 5 participants were selected. Selection of the participants was made based on the following criteria: (i) working with the NBC (ii) working in the programs departments of the two broadcast stations; (iii) was conversant with the with the NBC regulations codes and/or monitoring broadcast stations' compliance to the code or otherwise; and (iv) was conversant with the programs production and presentation (i.e., conversant with the programs schedules) of the broadcast organizations. The participants were management personnel of the Maiduguri office of the NBC, four (two management and two programs department) personnel each of BRTV and NTA Maiduguri respectively. To ensure anonymity and to facilitate smoother data analysis, each participant was assigned a serial number (see Lindlof \& Taylor, 2002). Key informant interview methodology was chosen because key informants reveal information from organizational insiders, or stakeholders, i.e., management staff members responsible for policy making and crafting messages and key stakeholders (Lindlof \& Taylor, 2002). The data were analyzed using thematic approach (Van Dijk, 1993). Cited in Tijani-Adenle (2019, p.88), thematic analysis is:

An independent approach within the qualitative descriptive methodologies" (Vaismoradi, Turunen \& Bondas, 2013, p.404) that involves identifying similarities and relationships in qualitative data known as "themes and patterns" (Aronson, 1995, p.1) and analyzing and explaining their meanings to reflect the "complex relationships across participants' experiences" (Henderson \& Baffour, 2015, p.1965).

\section{Results and Discussion}

Four different program schedules from NTA Maiduguri and BRTV were obtained. Additionally, Heads of programs in the two organizations were interviewed, while the Zonal Coordinator of NBC Maiduguri Office was interviewed.

RQ2 sought to know the religious programs and their broadcast time (air time) on both BRTV and NTA Maiduguri. To answer this RQ, the program schedules of BRTV and NTA Maiduguri for the Ramadan 2019 period and beyond, that is, the second quarter of 2019 (Q2) were obtained and analyzed. Tables 1 to 4 show the extracted schedules for religious programs broadcast on BRTV Maiduguri.

Table 1 shows the program schedule for the month of Ramadan. Apparently, religious programmes occupy the entire schedule. The programs were $100 \%$ religious, even though there is provision for the broadcast of news of the day, which lasts 30 minutes or so. Worthy of note is that, there is break in between the morning and afternoon transmission. In previous Ramadan as noted by Imam (personal communication, 2019), the break is usually cancelled, because of the traffic in the number of religious programs willing to pay for airtime and get aired. Sponsors of most of the programs have permanently booked prime time.

Table 1. The inventory of religious programs contained in the program schedule of BRTV Maiduguri

\begin{tabular}{|l|l|l|l|l|c|}
\hline \multicolumn{1}{|c|}{ Title of Program } & \multicolumn{1}{|c|}{ Presenter } & $\begin{array}{c}\text { Time of } \\
\text { Broadcast }\end{array}$ & Duration & \multicolumn{1}{c|}{ Sponsor } & Genre \\
\hline $\begin{array}{l}\text { Tafseer from Government } \\
\text { House Maiduguri }\end{array}$ & $\begin{array}{l}\text { Sheikh Ibrahim } \\
\text { Mustapha Al- } \\
\text { Malik }\end{array}$ & $7: 00 \mathrm{am}$ & One hour & Free & Recorded \\
\hline $\begin{array}{l}\text { Tafseer from Imam } \\
\text { Bukhari Mosque }\end{array}$ & $\begin{array}{l}\text { Sheikh Modu } \\
\text { Mustapha }\end{array}$ & $8: 00 \mathrm{am}$ & One hour & Unknown & Recorded \\
\hline Tafseer from Hausari & $\begin{array}{l}\text { Sheikh Kabiru } \\
\text { Danyaya }\end{array}$ & $9: 00 \mathrm{am}$ & One hour & Unknown & Recorded \\
\hline $\begin{array}{l}\text { Tafseer from Umar Ibn } \\
\text { Khattab Mosque } \\
\text { Bulumkutu }\end{array}$ & $\begin{array}{l}\text { Sheikh Babunu } \\
\text { Bukar }\end{array}$ & $10: 00 \mathrm{am}$ & One hour & $\begin{array}{l}\text { Umar Ibn Khattab } \\
\text { Mosque }\end{array}$ & Recorded \\
\hline $\begin{array}{l}\text { Tafseer from Taha } \\
\text { Qur'anic Memorisation } \\
\text { Centre }\end{array}$ & $\begin{array}{l}\text { Imam Goni } \\
\text { Muhammad Ali } \\
\text { Gapchiya }\end{array}$ & $11: 00 \mathrm{am}$ & One hour & $\begin{array}{l}\text { Taha Qur'anic } \\
\text { Memorization Centre }\end{array}$ & Recorded \\
\hline $\begin{array}{l}\text { Tafseer from Shettima Ali } \\
\text { Monguno Mosque Mafoni }\end{array}$ & $\begin{array}{l}\text { Goni Modu Goni } \\
\text { Zarami }\end{array}$ & $12: 00 \mathrm{pm}$ & One hour & Unknown & Recorded \\
\hline $\begin{array}{l}\text { Tafseer from Central } \\
\text { Mosque }\end{array}$ & Goni Abba Umar & $1: 00 \mathrm{pm}$ & One hour & Free & Recorded \\
\hline $\begin{array}{l}\text { Tafseer from Al-Umma } \\
\text { Mosque Board of Internal } \\
\text { Revenue }\end{array}$ & $\begin{array}{l}\text { Dr Muhammad } \\
\text { Abubakar Talha }\end{array}$ & $4: 00 \mathrm{pm}$ & One hour & $\begin{array}{l}\text { Board of Internal } \\
\text { Revenue }\end{array}$ & Recorded \\
\hline
\end{tabular}




\begin{tabular}{|l|l|l|l|l|c|}
\hline \multicolumn{1}{|c|}{ Title of Program } & \multicolumn{1}{|c|}{ Presenter } & \multicolumn{1}{c|}{$\begin{array}{c}\text { Time of } \\
\text { Broadcast }\end{array}$} & Duration & \multicolumn{1}{c|}{ Sponsor } & Genre \\
\hline $\begin{array}{l}\text { Tafseer from 1000 } \\
\text { Ahmad Jaha Foundation }\end{array}$ & $\begin{array}{l}\text { Late Dr Ali } \\
\text { Mustapha }\end{array}$ & $5: 00 \mathrm{pm}$ & One hour & Ahmad Babawo Jaha & Recorded \\
\hline $\begin{array}{l}\text { Bayan kla Asham mben } \\
\text { (Kanuri) }\end{array}$ & $\begin{array}{l}\text { Any prominent } \\
\text { scholar }\end{array}$ & $6: 25 \mathrm{pm}$ & $\begin{array}{l}5 \\
\text { minutes }\end{array}$ & Free & Recorded \\
\hline $\begin{array}{l}\text { Jawabi Kan Azumi } \\
\text { (Hausa) }\end{array}$ & $\begin{array}{l}\text { Any prominent } \\
\text { scholar }\end{array}$ & $6: 25 \mathrm{pm}$ & 5 & Free & Recorded \\
\hline $\begin{array}{l}\text { Tafseer from Al-Amin } \\
\text { Daggash Mosque (Hausa) }\end{array}$ & $\begin{array}{l}\text { Sheikh } \\
\text { Muhammad } \\
\text { Mustapha }\end{array}$ & $8: 00 \mathrm{pm}$ & One hour & $\begin{array}{l}\text { Al-Amin Daggash } \\
\text { Islamic Foundation }\end{array}$ & Recorded \\
\hline $\begin{array}{l}\text { Tafseer from Ibrahim } \\
\text { Saleh Mosque Gwange } \\
\text { (Hausa) }\end{array}$ & $\begin{array}{l}\text { Sheikh Ibrahim } \\
\text { Saleh }\end{array}$ & $9: 00 \mathrm{pm}$ & One hour & $\begin{array}{l}\text { Sheikh Ibrahim } \\
\text { Saleh Islamic } \\
\text { Foundation }\end{array}$ & Recorded \\
\hline $\begin{array}{l}\text { Tafseer from Indimi } \\
\text { Mosque (Hausa) }\end{array}$ & $\begin{array}{l}\text { Dr Muhammad } \\
\text { Alhaji Abubakar }\end{array}$ & $10: 00 \mathrm{pm}$ & One hour & Indimi Islamic Trust & Recorded \\
\hline $\begin{array}{l}\text { Tafseer from Imam Malik } \\
\text { Islamic Centre (Kanuri) }\end{array}$ & $\begin{array}{l}\text { Sheikh Abubakar } \\
\text { Kyari }\end{array}$ & $11:: 00 \mathrm{pm}$ & One hour & $\begin{array}{l}\text { Imam Malik Islamic } \\
\text { Centre }\end{array}$ & Recorded \\
\hline $\begin{array}{l}\text { Tafseer from } \\
\text { MOGCOLIS Mosque }\end{array}$ & $\begin{array}{l}\text { Sheikh Tijjani } \\
\text { Umara }\end{array}$ & $12: 00 \mathrm{pm}$ & One hour & MOGCOLIS & Recorded \\
\hline
\end{tabular}

Source: BRTV field work, 2019

Table 2 contains a breakdown of religious programs broadcast for the $2^{\text {nd }}$ Quarter of 2019. The $2^{\text {nd }}$ quarter supersedes the one month-long Ramadan fasting period.

Table 2. The inventory of religious programs contained in the program schedule of BRTV Maiduguri for the $2^{\text {nd }}$ Quarter of 2019

\begin{tabular}{|c|c|c|c|c|c|}
\hline Title of The Program & Presenter & $\begin{array}{c}\text { Days of } \\
\text { Broadcast }\end{array}$ & Time & Duration & Sponsor \\
\hline MCAN Da'awah & $\begin{array}{l}\text { Alternating members of } \\
\text { Muslim Corpers } \\
\text { Association of Nigeria }\end{array}$ & Sunday & 9:00am & 30 minutes & Free \\
\hline $\begin{array}{l}\text { Babban Guzuri } \\
\text { (Hausa) Repeat } \\
\text { broadcast }\end{array}$ & $\begin{array}{l}\text { Sheikh Muhammad } \\
\text { Mustapha }\end{array}$ & Sunday & $11 \mathrm{pm}$ & One hour & $\begin{array}{l}\text { Ahmed Babawo } \\
\text { Jaha }\end{array}$ \\
\hline Riyadus Saliheen & Sheikh Abubakar Kyari & Sunday & 9:00pm & One hour & $\begin{array}{l}\text { Imam Malik } \\
\text { Islamic Centre }\end{array}$ \\
\hline $\begin{array}{l}\text { Tafseer from } \\
\text { Government House } \\
\text { (Hausa) }\end{array}$ & & Sunday & 11:00pm & One hour & Free \\
\hline $\begin{array}{l}\text { Tafseer Indimi } \\
\text { Mosque (Hausa) }\end{array}$ & $\begin{array}{l}\text { Dr Muhammad Alhaji } \\
\text { Abubakar }\end{array}$ & Monday & $11 \mathrm{pm}$ & One hour & $\begin{array}{l}\text { Indimi Islamic } \\
\text { Trust }\end{array}$ \\
\hline $\begin{array}{l}\text { FOMWAN Da'awah } \\
\text { (Hausa or Kanuri) }\end{array}$ & $\begin{array}{l}\text { Alternating FOMWAN } \\
\text { members }\end{array}$ & Tuesday & 09:00am & 30 Minutes & Free \\
\hline $\begin{array}{l}\text { Tafseer from Al- } \\
\text { Ansar Mosque } \\
\text { (Hausa) }\end{array}$ & Dr Yahuza Abdullahi & Tuesday & 11:00am & One hour & $\begin{array}{l}\text { Al-Ansar } \\
\text { Mosque }\end{array}$ \\
\hline $\begin{array}{l}\text { Tafseer from Hausari } \\
\text { Layin Sarkin } \\
\text { Hausawa }\end{array}$ & Sheikh Kabiru Danyaya & Tuesday & $11: 00 \mathrm{pm}$ & One hour & Unknown \\
\hline Islam Today & Ustaz Adebayo & Wednesday & 09:00am & 30 minutes & Free \\
\hline Nur Islambe (Hausa) & $\begin{array}{l}\text { Sheikh Muhammad } \\
\text { Mustapha }\end{array}$ & Wednesday & 11:00am & One hour & Unknown \\
\hline $\begin{array}{l}\text { Tafseer from Imam } \\
\text { Malik (Kanuri) }\end{array}$ & Sheikh Abubakar Kyari & Wednesday & 08:00pm & One hour & $\begin{array}{l}\text { Imam Malik } \\
\text { Islamic Centre }\end{array}$ \\
\hline $\begin{array}{l}\text { Tafseer Daggash } \\
\text { Mosque (Hausa) }\end{array}$ & $\begin{array}{l}\text { Sheikh Muhammad } \\
\text { Mustapha }\end{array}$ & Wednesday & 11:00pm & One hour & $\begin{array}{l}\text { Al-Amin } \\
\text { Daggash } \\
\text { Islamic Centre }\end{array}$ \\
\hline Fiqh & $\begin{array}{l}\text { Alternating Sheikh Yunus } \\
\text { and Late Dr Ali Mustapha }\end{array}$ & Thursday & 09:00am & 30 minutes & Free \\
\hline
\end{tabular}




\begin{tabular}{|c|c|c|c|c|c|}
\hline Title of The Program & Presenter & $\begin{array}{c}\text { Days of } \\
\text { Broadcast }\end{array}$ & Time & Duration & Sponsor \\
\hline $\begin{array}{l}\text { Islamic Medicine } \\
\text { (Hausa) }\end{array}$ & Mal Ja'afar & Thursday & 10:00am & 30 minutes & Free \\
\hline Islamic Quiz (Hausa) & Alternating & Thursday & $04: 30 \mathrm{pm}$ & 30 minutes & Free \\
\hline $\begin{array}{l}\text { Tafseer from } \\
\text { MOGCOLIS (Hausa) }\end{array}$ & Sheikh Tijjani Umara & Thursday & $11: 00 \mathrm{pm}$ & One hour & MOGCOLIS \\
\hline Qur'anic recitation & Alternating & Friday & 08:00am & $\begin{array}{l}\text { No specific } \\
\text { duration }\end{array}$ & Free \\
\hline $\begin{array}{l}\text { Al'ulamu rashidun } \\
\text { (Hausa or Kanuri, } \\
\text { live) program }\end{array}$ & Alternating scholars & Friday & 10:00am & One hour & Free \\
\hline $\begin{array}{l}\text { You and Islam } \\
\text { (Documentary) }\end{array}$ & Nil & Friday & 11:00am & 30 minutes & Free \\
\hline Babban Guzuri & $\begin{array}{l}\text { Sheikh Muhammad } \\
\text { Mustapha }\end{array}$ & Friday & 08:00pm & One hour & $\begin{array}{l}\text { Ahmed Babawo } \\
\text { Jaha }\end{array}$ \\
\hline $\begin{array}{l}\text { Tafseer from Shettima } \\
\text { Ali Monguno Mosque } \\
\text { Mafoni }\end{array}$ & Goni Modu Goni Zarami & Friday & $11: 00 \mathrm{pm}$ & One hour & Unknown \\
\hline Hadith (Kanuri) & Goni Abba Umar & Saturday & 05:00pm & 30 minutes & Free \\
\hline Tarbiya (Hausa) & $\begin{array}{l}\text { Dr Muhammad Alhaji } \\
\text { Abubakar }\end{array}$ & Saturday & $08 ; 00 \mathrm{pm}$ & One hour & Free \\
\hline $\begin{array}{l}\text { Tafseer from Taha } \\
\text { Qur'anic } \\
\text { Memorization Centre }\end{array}$ & Imam Goni Ali Modu & Saturday & $11: 00 \mathrm{pm}$ & One hour & $\begin{array}{l}\text { Taha Qur'anic } \\
\text { Memorization } \\
\text { Centre }\end{array}$ \\
\hline
\end{tabular}

Source: BRTV, field work 2019

Table 3 contains programs broadcast during the 2019 Ramadan fasting period.

Table 3. The inventory of religious programs contained in the program schedule of NTA Maiduguri Ramadan

\begin{tabular}{|c|c|c|c|c|c|}
\hline Title of Program & Presenter & $\begin{array}{c}\text { Time of } \\
\text { Broadcast }\end{array}$ & Duration & Sponsor & Genre \\
\hline $\begin{array}{l}\text { Tafseer from Ansar } \\
\text { Mosque }\end{array}$ & $\begin{array}{l}\text { Dr Yahuza } \\
\text { Abdullahi }\end{array}$ & $8: 00-8: 55 \mathrm{Pm}$ & One hour & Ansar Mosque & Recorded \\
\hline $\begin{array}{l}\text { Tafseer from Imam } \\
\text { Malik Centre }\end{array}$ & $\begin{array}{l}\text { Sheikh Abubakar } \\
\text { Kyari }\end{array}$ & $\begin{array}{l}10: 00- \\
10: 55 \mathrm{pm}\end{array}$ & One hour & $\begin{array}{l}\text { Imam Malik } \\
\text { Islamic Centre }\end{array}$ & Recorded \\
\hline $\begin{array}{l}\text { Tafseer from Indimi } \\
\text { Mosque }\end{array}$ & $\begin{array}{l}\text { Dr Muhammad } \\
\text { Alhaji Abubakar }\end{array}$ & $\begin{array}{l}11: 00- \\
12: 00 \mathrm{pm}\end{array}$ & One hour & $\begin{array}{l}\text { Indimi Islamic } \\
\text { Trust }\end{array}$ & Recorded \\
\hline $\begin{array}{l}\text { *Tafseer from } \\
\text { Government House }\end{array}$ & $\begin{array}{l}\text { Sheikh Ibrahim } \\
\text { Mustapha Al- } \\
\text { Malik }\end{array}$ & $\begin{array}{l}06: 00- \\
06: 55 \mathrm{am}\end{array}$ & One hour & Free & Recorded \\
\hline $\begin{array}{l}* * \text { Tafseer from } \\
\text { Maiduguri Central } \\
\text { Mosque }\end{array}$ & Goni Abba Umar & $\begin{array}{l}06:: 00- \\
06:: 55 \mathrm{am}\end{array}$ & One hour & Free & Recorded \\
\hline $\begin{array}{l}\text { Tafseer from Al-Amin } \\
\text { Daggash Mosque }\end{array}$ & $\begin{array}{l}\text { Sheikh Muhammad } \\
\text { Mustapha }\end{array}$ & $\begin{array}{l}10: 00- \\
10: 55 \mathrm{am}\end{array}$ & One hour & $\begin{array}{l}\text { Al-Amin Daggash } \\
\text { Islamic Foundation }\end{array}$ & Recorded \\
\hline $\begin{array}{l}\text { Tafseer from Izala Jos } \\
\text { faction, Gwange Mosque }\end{array}$ & $\begin{array}{l}\text { Sheikh Muhammad } \\
\text { Musa Bako }\end{array}$ & $\begin{array}{l}11: 00- \\
11: 55 \mathrm{am}\end{array}$ & One hour & Izala Jos faction & Recorded \\
\hline ***Jawabi Kan Azumi & $\begin{array}{l}\text { Any prominent } \\
\text { scholar based in } \\
\text { Maiduguri }\end{array}$ & $\begin{array}{l}06: 55- \\
07: 00 \mathrm{pm}\end{array}$ & 5 minutes & Free & Recorded \\
\hline $\begin{array}{l}* * * * \text { Bayan kla Ashem } \\
\text { mben }\end{array}$ & $\begin{array}{l}\text { Any prominent } \\
\text { scholar based in } \\
\text { Maiduguri }\end{array}$ & $\begin{array}{l}06: 55- \\
07: 00 \mathrm{pm}\end{array}$ & 5 minutes & Free & Recorded \\
\hline
\end{tabular}

Source: Field work, NTA 2019

**** The programs were broadcast interchangeably. They have similar synopsis and content, but different language of broadcast.

Table 4 indicates the religious programs broadcast on NTA Maiduguri after the month of Ramadan. 
Table 4. The inventory of religious programs contained in the program schedule of NTA Maiduguri for the $2^{\text {nd }}$ Quarter of 2019

\begin{tabular}{|l|l|l|l|l|}
\hline \multicolumn{1}{|c|}{ Title of Program } & \multicolumn{1}{|c|}{ Presenter } & \multicolumn{1}{c|}{$\begin{array}{c}\text { Time and Day of } \\
\text { Broadcast }\end{array}$} & Duration & \multicolumn{1}{c|}{ Sponsor } \\
\hline Nasiha in Hausa & $\begin{array}{l}\text { Any prominent scholar } \\
\text { based in Maiduguri }\end{array}$ & $\begin{array}{l}5: 00 \mathrm{pm}, \text { every } \\
\text { Thursday }\end{array}$ & 30 minutes & Free \\
\hline Hadith in Kanuri & $\begin{array}{l}\text { Any prominent scholar } \\
\text { based in Maiduguri }\end{array}$ & $5: 00 \mathrm{pm}$, every Friday & 30 minutes & Free \\
\hline Christian Half Hour & $\begin{array}{l}\text { Pastor and members of } \\
\text { choir }\end{array}$ & $\begin{array}{l}3: 00 \mathrm{pm}, \text { every } \\
\text { Sunday }\end{array}$ & 30 minutes & Free \\
\hline $\begin{array}{l}\text { No title. However, the } \\
\text { synopsis is clear. }\end{array}$ & Nil & $\begin{array}{l}12: 00 \mathrm{pm}, \text { every } \\
\text { Sunday }\end{array}$ & 30 minutes & $\begin{array}{l}\text { Christ } \\
\text { Embassy }\end{array}$ \\
\hline $\begin{array}{l}\text { Tafseer from Indimi } \\
\text { Mosque }\end{array}$ & $\begin{array}{l}\text { Late Sheikh Jaafar } \\
\text { Mahmud Adam }\end{array}$ & $\begin{array}{l}5: 00 \mathrm{pm}, \text { every } \\
\text { Wednesdays }\end{array}$ & One hour & $\begin{array}{l}\text { Indimi Islamic } \\
\text { Trust }\end{array}$ \\
\hline
\end{tabular}

Source: NTA Maiduguri field work, 2019

RQ3: How frequent do BRTV and NTA Maiduguri broadcast religious programs?

Based on the program schedule obtained from the two stations, findings reveal that religious programs have a higher percentage of airtime allocation. In BRTV for instance, out of 18 programs broadcast in a day (for morning and evening transmissions), 10 programs are religious (Imam, Personal communication 2019). In Ramadan, all programs with the exception of news, are suspended. Because they have been paid for, religious programs don't fail, and repeat versions are avoided, except on rare occasion. Imam attributed this to the fact Borno is a Muslim state, as such they give priority attention to programs with Islamic coloration. In NTA Maiduguri as noted by Gana (personal communication, 2019), there are only four religious programs: 2 Islamic and 2 Christian.

RQ 4: What are similarities in the mode of broadcast of religious programs in BRTV \& NTA Maiduguri?

Most of the religious programs are duplicated in both stations. In fact, some bear the same name, synopsis and style. Majority of the Islamic programs in BRTV are recorded, except for Al'ulamu rashidun which is LIVE and free of charge. In NTA, all the religious programs are recorded, and broadcast free of charge except for a Christian program that has gotten sponsorship from Christ Embassy.

The two stations have allocated time for the broadcast of religious programs at an odd time that is not prime time. The time is usually not characterized by heavy viewers.

RQ 5: Are there ethical violations on religious programs broadcast on BRTV and NTA Maiduguri?

During Ramadan, the two stations allocate more than $10 \%$ of the total airtime to religious programs. In BRTV for instance, there is no balance in the broadcast of religious programs. There is no single Christian program for the Christian viewer. Given the fact that Borno is a secular state with Muslim majority, however, there is need for balance.

Imam (personal Communication, 2019) told these researchers that since 1992 there has not been any Christian program on BRTV. Christian issues are only covered in news. This is not farfetched from staff composition, viewers need and perhaps absence of sponsors.

NBC had written several letters to BRTV to downplay religious programs...

In NTA, there seems to be balance. While Islamic religious programs are broadcast in Hausa and Kanuri, because viewers and Muslims are predominantly Hausa and Kanuri speakers, Christian programs are also in English. Each program address viewers appeal. Gana (personal communication, 2019) notes that the religious programs are locally produced, and each scholar invited as a guest or discussant in the programs, comes with his student to serve as an anchor.

Religious broadcast in Nigeria Television Authority (NTA) Maiduguri and Borno Radio Television (BRTV) occupies an important place in programs schedules. The two television stations place high premium on their broadcast during Ramadan and beyond. The turnover generated from the broadcast of religious content in Ramadan is significantly higher than any other month. BRTV charges the sum of two hundred and fifty thousand Naira for the transmission of religious content for the period of Ramadan, while outside Ramadan, it charges one hundred and fifty thousand Naira (Muhammad, personal communication, 2019).

According to Mele (personal communication, 2019) NTA Maiduguri on the other hand charges the sum of five hundred thousand Naira per religious broadcast for the month of Ramadan (though, subjects to bargain), while outside the month of Ramadan, it charges three hundred and ninety thousand Naira for the quarter.

\section{Conclusion}

It is the conclusion of the study that religious programs play a key role managing and sustaining the operations of BRTV and NTA Maiduguri during Ramadan. The stations sales airtime to highest bidders. The Ramadan period is a time for making brisk business. The acceptance of religious content for broadcast on public and 
private media organizations in Nigeria is a welcome phenomenon. The proliferation of religious content on the media has given rise to an alarming dimension in ethical violations of broadcasting codes, promotion of hate speeches among contending and conflicting ideologies in Nigeria. Inter-sect cum intra sect conflicts have been part challenges that gave rise to ethical violations and hate speeches by religious scholars during media programming.

The media outlets according to Ahmad \& Isa (2017) serve as arenas for proselytization, enlightenment and Islamic propagation. They are utilized as springboard where Islamic groups peddle their doctrines and belief system. Because of the opportunity provided by the media to everybody especially those with the purchasing power, Islamic scholars take this advantage in their various public outings which are broadcast on the media to construct their unique identities, respond to criticisms (in harsh or low tone) and perhaps condemnations in adversarial manner.

\section{References}

Adebiyi, R. A. \& Salaudeen, K. A. (2016). The changing face of political communication in Nigeria: A do-or-die media game. In D. Wilson (Ed.), Mass media and the electoral process in Nigeria (pp.209-220). Uyo: ACCE.

Adum, A. N. \& Ojiakor, O. E. \& Nnatu, S. (2019). Party politics hate speech and the media: A developing society perspective. Journal of Humanities and Social Policy, 5(1), 2545-5729.

Ahmad, G. \& Isa, K. H. (2017). Islamic groups and contestation for religious public space on radio stations in Kano Metropolis. In U. A. Pate \& L. Oso (Eds.), Multiculturalism, diversity and reporting conflict in Nigeria. Ibadan: Evans Brothers Limited.

Anifowose, B. O. (2013). Exploring radio as a means of disseminating development messages. Department of Communication and Language Art. University of Ibadan, Ibadan. Nigeria.

Bala, M. (2000). Pluralism and prior restraint on religious communication in Nigeria: Policy versus Praxis. In J. Thierstein \& Y. R. Kamalipour (Eds.), Religion, law, and Freedom: A Global Perspective (pp. 98-111). London: Praeger.

Creswell, J. W. \& Poth, C. N. (2017). Qualitative inquiry and research design: Choosing among five approaches. New Delhi: Sage Publications.

Damaris P. S. (2006). Then sings my soul': Gospel music as popular culture in the spiritual lives of Kenyan Pentecostal/Charismatic Christians". Journal of Religious and Popular Culture, XIV. Retrieved from http://www.usask.ca/relst/jrpc/art14-singsmysoul.html

Dominick, J.R. (2009). The dynamics of mass communication: Media in the digital age (10th ed.). New York: McGraw-Hill.

Falola, T. \& Heaton, M. M. (2008). A history of Nigeria. Cambridge: Cambridge University Press.

Goodwin, C. (2009). Research in psychology: Methods and design. Hoboken, NJ.: John Wiley and Sons.

Hackett, R. I. J. (1998). Charismatic/Pentecostal appropriation of media technologies in Nigeria and Ghana. Journal of Religion in Africa, XXVIII(3), 258-277.

Harvey, S. (1999). Broadcasting regulation: On the side of the angels? Retrieved from http://www.latrobe.edu.au/screeningthepast/firstrelease

Ibrahim, A. M. (2017). Factors affecting ICT usage for the development of small and medium-scale agro-based enterprises in Selangor, Malaysia, (Unpublished master's thesis), Universiti Putra Malaysia.

Ibrahim, A. M., Pate, U. A., \& Usman, A. M. (in press). Silencing the media and chaining the watchdog: Threats to journalists' safety during elections in Nigeria. In S. Jamal (Ed.), Combatting threats to media freedom and journalists' safety (ch. 12). Hershey: IGI Global.

Ibrahim, A. M., Yar'Adua, S. M. \& Maikaba, B. (2019). More media, less democratisation of public access and participation: A conceptual review on influence of deregulation and commercialisation on public broadcasting in Nigeria. International Journal of Telecommunications and Information Technology, 3(1), $32-46$.

Ihechu, I. P. (2019). Broadcasting and promotion of development in Sub-Saharan Africa. Journal of Development and Communication Studies, 6(1), 48-60.

Ihechu, I. P. \& Okugo, U. C. (2013). Broadcasting regulation and broadcasting in Nigeria: An overview of the approaches. Research on Humanities and Social Sciences, 3(2), 12-19.

Jeffrey, C. L. (1996). An ethics code postmortem: The National Religious Broadcasters' EFICOM. Journal of Mass Media Ethics, 11(4), 223-235.

Johannes, H. (2008). Democratization and Islamic Law: The Sharia Conflict in Nigeria, Frankfurt: Campus Verlag.

Lindlof, T. R., \& Taylor, B. C. (2002). Qualitative communication research methods, Thousand Oaks, CA: Sage. 
Malaolu, P. O. (2012). Media representation and democracy in Africa: 'Why there are no skyscrapers in Nigeria' - A critical analysis of UK news media's representation of Nigeria's democracy, 1997-2007. (Unpublished doctoral dissertation). University of Sterling, UK.

Marshall, C. \& Rossman, G. B. (2014). Designing qualitative research. London: Sage publications.

McBurney, D. \& White, T. (2009). Research methods (8th Ed.). Belmont, CA: Wadworth, Centage Learning.

NBC (2009, September 3). Grant of radio and television network service licenses. [Information Memorandum] Abuja: Retrieved from http://www.nbc.gov.org.php?

Nwanze, I. (2003). Broadcasting in Nigeria: Private broadcasting, prospects, challenges, legal aspects. Port Harcourt: Renaissance Communications Ltd.

Okunna, C. (2005 January). Re-inventing media content in Nigeria: Creating a balance between social responsibility and business concern. International Journal of Communication, 2, 89-96.

Owuamalam, E (2006). Introduction to broadcasting. Owerri: Top class Agencies Ltd.

Tijani-Adenle, G. (2019). Women in Nigerian news media: Status, experiences and structures. (Unpublished doctoral thesis), De Montfort University, Leicester, the United Kingdom.

Ukah, A. (2011). Banishing miracles: politics and policies of religious broadcasting in Nigeria. Politics and Religion, $1(\mathrm{~V}), 39-60$.

Van Dijk, T. A. (1993). Principles of critical discourse analysis. Discourse and Society, 4(2), 249-283. doi: $10.1177 / 0957926593004002006$ 